\title{
Agrobacterium tumefaciens-mediated transformation of rice with the spider insecticidal gene conferring resistance to leaffolder and striped stem borer
}

\author{
HUANG JiAn QIU ${ }^{1, *}$, ZHi Ming WEI ${ }^{1}$, HaI LoNG $\mathrm{AN}^{1}$, Yu XIAN ZHU ${ }^{2}$
}

1 National Laboratory of Plant Molecular Genetics, Institute of Plant Physiology and Ecology, Shanghai Institute for Biological Sciences, Chinese Academy of Sciences, Shanghai 200032, China

2 National Laboratory of Plant Genetic Engineering and Protein Engineering, College of Life Science, Peking University, Beijing 100871, China

\begin{abstract}
Immature embryos of rice varieties "Xiushui11" and "Chunjiang 11" precultured for 4d were infected

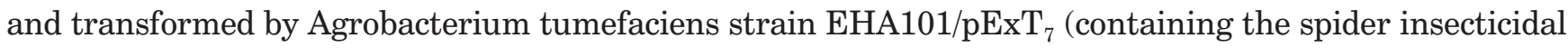
gene). The resistant calli were transferred onto the differentiation medium and plants were regenerated. The transformation frequency reached 56\% 72\% measured as numbers of Geneticin (G418)- resistant calli produced and 36\% 60\% measured as numbers of transgenic plants regenerated, respectively. PCR and Southern blot analysis of transgenic plants confirmed that the T-DNA had been integrated into the rice genome. Insect bioassays using $\mathrm{T} 1$ transgenic plants indicated that the mortality of the leaffolder (Cnaphalocrasis medinalis) after $7 \mathrm{~d}$ of leaf feeding reached $38 \% \sim 61 \%$ and the corrected mortality of the striped stem borer (Chilo suppressalis) after $7 \mathrm{~d}$ of leaf feeding reached $16 \% \sim 75 \%$. The insect bioassay results demonstrated that the transgenic plants expressing the spider insecticidal protein conferred enhanced resistance to these pests.
\end{abstract}

Key words: Rice, Agrobacterium tumefaciens, spider insecticidal gene, transgenic plant, Leaffolder, striped stem borer, insect bioassay.

\section{INTRODUCTION}

Rice is one of the world' s most important food crops. Although a decade ago rice was considered as one of the most recalcitrant crops in terms of genetic manipulation, it has recently emerged as the model cereal for the study of plant genomics, plant pathology, gene regulation and expression, metabolic pathway manipulation and the inheritance, organization, rearrangement and fate of transgenes[1],[2]. Remarkable progress has been made in the development of systems for Agrobacterium tumefaciences -mediated transformation in rice since 1994[3-8]. However, until now,

\footnotetext{
* Corresponding author.

Fax: 8621-64042385; E-mail: jqhuang@iris.sipp.ac.cn

Abbreviations: $\mathrm{SpI}=$ spider insecticidal gene; $\mathrm{BAP}=\mathrm{N} 6$ benzyladene; NAA=a-naphthalene acetic acid; $2,4-\mathrm{D}=2,4$ dichlorophenoxy acetic acid; $\mathrm{CH}=$ casein, acid hydrolysate; $\mathrm{AS}=$ acetosyringone; $\mathrm{Cef}=$ cefotaxime Kan=kanamycin; $\mathrm{G}$ $418=$ Geneticin; $\mathrm{SSB}=$ striped stem borer; $\mathrm{LF}=$ leaffolder.

Received Jan-31-2001 Revised April-28-2001 Accepted April-30-2001
}

only a few studies have been reported on A. tumefaciences-mediated transformation of rice using genes of agronomic importance to increase its resistance to pests[9],[10], and the numbers of plants obtained and the transformation frequencies in most of the studies mentioned above were unfortunately still very low (usually below 30\%) from a breeder's point of view. Recently, more than 970 transgenic plants were produced with the modified SpI gene in two rice cultivars by using a modified Agrobacterium-based rice transformation procedure in our laboratory [7], PCR and Southern blot analysis indicated that the foreign genes had been integrated into the rice genome, and genetic analysis confirmed Mendelian segregation of the transgenes in subsequent generations. Insect feeding assays with the T1 plant tissues indicated that most of the transgenic plants tested were highly toxic to two major rice insects, striped stem borer 
and leaffolder, with near 38\%-72\% mortality within $7 \mathrm{~d}$ after infestation with few exception. Here we describe, for the first time, a method to efficiently

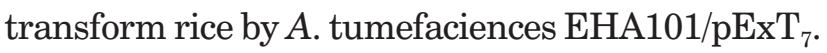
We produced a large number of transformants of two rice cultivars and demonstrated stable integration, expression, and inheritance of transgenes.

\section{MATERIALS AND METHODS}

\section{Plant materials and culture media}

Japonica rice cultivars: Xiushui 11, Chunjiang 11 were used in transformation studies. Media used for tissue culture and transformation are listed in Tab 1. Immature seeds were dehusked, first sterilized with $75 \%$ ethanol for $2 \mathrm{~min}$ and then 6 . $7 \%$ sodium hypochlorite for $15 \mathrm{~min}$. The seeds were further washed 3 times with sterilized deionized water. The immature embryos were dissected aseptically and cultured on solid $\mathrm{N}_{6}[11]$ medium with $2 \mathrm{mg} / \mathrm{L} 2,4-\mathrm{D}$ (designated $\mathrm{N}_{6} \mathrm{D}_{2}$ ). The cultures were incubated in the dark at $25 \pm$ plusmnl; $1^{\circ} \mathrm{C}$ for $4-5 \mathrm{~d}$, the compact calli (1-2 mm in diameter) derived from the scutella were separated with scalpel and used for transformation.

\section{A. tumefaciens strains, plasmid and culture}

A. tumefaciens EHA101 harboring binary vector $\mathrm{pExT}_{7}$ were used for the experiment. $\mathrm{pExT}_{7}$ contained $\mathrm{SpI}$ (spider insect toxin) gene and nptII gene as a selectable marker within the T-DNA region. Each gene was under the control of an enhanced CaMV35S promoter (P35S). A. tumefaciens were grown over-

Tab 1. Media used for tissue culture and transformation of rice

\begin{tabular}{|c|c|}
\hline Medium & Composition \\
\hline N6D2 & $\begin{array}{l}\text { N6[11], } 500 \mathrm{mg} / \mathrm{L} \text { casamino acids, } 30 \mathrm{~g} / \mathrm{L} \\
\text { sucrose, } 2 \mathrm{mg} / \mathrm{L} 2,4-\mathrm{D}, 6.5 \mathrm{~g} / \mathrm{L} \text { agar, } \mathrm{pH} 5.8\end{array}$ \\
\hline N6D2-AS & N6D2 medium plus $100 \mu \mathrm{M}$ acetosyringone \\
\hline AAD1 & $\begin{array}{l}\mathrm{AA}[12], 500 \mathrm{mg} / \mathrm{L} \text { casamino acids, } 30 \mathrm{~g} / \mathrm{L} \\
\text { sucrose, } 1 \mathrm{mg} / \mathrm{L} 2,4-\mathrm{D}, \mathrm{pH} 5.6\}\end{array}$ \\
\hline AAD1-AS & AAD1 medium plus $100 \mu \mathrm{M}$ acetosyringone \\
\hline N6CD2-CG & $\begin{array}{l}\mathrm{N}_{6} \mathrm{CD}_{2} \text { medium plus } 300 \mathrm{mg} / \mathrm{L} \text { cefotaxime and } \\
25-50 \mathrm{mg} / \mathrm{L} \mathrm{G}-418\end{array}$ \\
\hline RE1-CG & $\begin{array}{l}\mathrm{MS}[13], 30 \mathrm{~g} / \mathrm{L} \text { sucrose, } 10-20 \mathrm{~g} / \mathrm{L} \text { sorbitol, } 1- \\
2 \mathrm{~g} / \mathrm{L} \text { casamino acids, } 2 \mathrm{mg} / \mathrm{L} \text {-BA, } 0.25 \mathrm{mg} / \\
\mathrm{L} \mathrm{NAA}, 250 \mathrm{mg} / \mathrm{L} \text { cefotaxime and } 50 \mathrm{mg} / \mathrm{L} \mathrm{G} \text { - } \\
418,2.2 \mathrm{~g} / \mathrm{L} \text { gelrite, } \mathrm{pH} 5.8\end{array}$ \\
\hline RE2-G & $\begin{array}{l}\text { MS medium plus } 30 \mathrm{~g} / \mathrm{L} \text { sucrose, } 10 \mathrm{~g} / \mathrm{L} \\
\text { sorbitol, } 1-2 \mathrm{~g} / \mathrm{L} \text { casamino acids, } 2 \mathrm{mg} / \mathrm{L} 6- \\
\text { BA, } 0.5 \mathrm{mg} / \mathrm{L} \text { NAA, } 50 \mathrm{mg} / \mathrm{L} \mathrm{G}-418,2.2 \mathrm{~g} / \mathrm{L} \\
\text { gelrite, } \mathrm{pH} 5.8\end{array}$ \\
\hline MS0K & $\begin{array}{l}\text { MS major salts, MS minor salts and MS } \\
\text { vitamins, } 20 \mathrm{~g} / \mathrm{L} \text { sucrose, } 75 \mathrm{mg} / \mathrm{L} \text { Kanamycin, } \\
2.2 \mathrm{~g} / \mathrm{L} \text { gelrite, } \mathrm{pH} 5.8\end{array}$ \\
\hline $1 / 2 \mathrm{MSNK}$ & $\begin{array}{l}\text { Half-strength MS major salts, MS minor salts } \\
\text { and MS vitamins, } 0.5 \mathrm{mg} / \mathrm{L} \mathrm{NAA}, 20 \mathrm{~g} / \mathrm{L} \\
\text { sucrose, } 75 \mathrm{mg} / \mathrm{L} \text { kanamycin, } 2.2 \mathrm{~g} / \mathrm{L} \text { gelrite, } \\
\text { pH } 5.8\end{array}$ \\
\hline
\end{tabular}

night at $26^{\circ} \mathrm{C}$ with shaking (210 rpm) in liquid YEP medium (5 $\mathrm{g} / \mathrm{L}$ yeast extract, $10 \mathrm{~g} / \mathrm{L}$ peptone, $5 \mathrm{~g} / \mathrm{L} \mathrm{NaCl}, \mathrm{pH}$ 7.0) containing $50 \mathrm{mg} / \mathrm{L}$ kanamycin, $50 \mathrm{mg} / \mathrm{L}$ spectinomycin and $6 \mathrm{mg} / \mathrm{L}$ Tetracyclin with $100 \mu \mathrm{M}$ acetosyringone, to mid-log phase $(\mathrm{OD} 600=0.8-1.0)$. The culture was centrifuged at 3,000 rpm for 10 minutes and the pellet was resuspended in equal volume (usually $8 \sim 10 \mathrm{ml}$ ) of AAD1-AS medium (Tab 1) and used for co-cultivation.

\section{Co-cultivation, selection and plant regeneration}

The calli were soaked in bacterial suspension for $20 \mathrm{~min}$, blotted dry with sterile filter paper to remove excess bacteria. Then the calli were transferred on a piece of filter paper placed on a co-culture medium $\left(\mathrm{N}_{6} \mathrm{D}_{2}\right.$-AS). One $\mathrm{ml}$ of a liquid medium $\left(\mathrm{AAD}_{1}-\mathrm{AS}\right)$ was dripped onto the surface of the filter paper. The plates were sealed with parafilm. Co-cultivation was carried out in the dark at $26^{\circ} \mathrm{C}$ for $3 \mathrm{~d}$. The calli labeled as control were not infected with Agrobacterium. After co-cultivation, the infected calli were washed $3 \sim 5$ times with sterilized deionized water containing $500 \mathrm{mg} / \mathrm{L}$ cefotaxime to kill the Agrobacterium. The inoculated calli were first transferred to $\mathrm{N}_{6} \mathrm{D}_{2}$ medium containing $300 \mathrm{mg} / \mathrm{L}$ cefotaxime $\left(\mathrm{N}_{6} \mathrm{D}_{2} \mathrm{C}\right)$ for one week of callus growth without selection and then transferred to $\mathrm{N}_{6} \mathrm{D}_{2}$-CG medium (Tab 1). After selection for 3-4 w, resistant calli were transferred to RE1-CG medium for shoot development. The regenerated shoots were further transferred to RE2-G for full plantlet formation and then rooted on $1 / 2 \mathrm{MSNK}$ medium. After rooting, the transgenic plants were transferred to a glasshouse and grown to maturity.

\section{PCR and Southern blot analysis of transgenic plants}

1. DNA isolation Total genomic DNA was extracted from 0 . 2-1.0 g young leaf tissues of transgenic plants and untransformed control according to CTAB method[14].

2. Polymerase chain reaction (PCR) analysis The putative transgenic (G-418 resistant) plants were analyzed by PCR for the presence of the nptII transgenes. One pair of specific primers were used to detect the npt II gene: forward primer (P1) 5' AGAGGCGGCTATGACTGG-3' and reverse primer (P2) 5' ATCGCCATGGGACGAGAT-3' . The PCR reactions were carried out in a total volume of $30 \mu \mathrm{l}$, comprising $50 \mathrm{ng}$ of rice genomic DNA $(1 \mu \mathrm{l}), 20 \mathrm{pmol}$ of each primer, $200 \mu \mathrm{M}$ each dNTP, 0.5 units Taq DNA polymerase and $3 \mu 110 \times$ PCR buffer. DNA was denatured at $94^{\circ} \mathrm{C}$ for $5 \mathrm{~min}$ followed by 35amplification cycles $\left(94^{\circ} \mathrm{C}\right.$ for $45 \mathrm{~s}, 62^{\circ} \mathrm{C}$ for $1 \mathrm{~min}, 72^{\circ} \mathrm{C}$ for $1 \mathrm{~min}$ ) and $10 \mathrm{~min}$ at $72^{\circ} \mathrm{C}$.

3. Southern blot analysis Total genomic DNA was isolated from 3-8 $\mathrm{g}$ fresh weight leaf material according to the manufacturer's instructions[15]. A 10- $\mu \mathrm{g}$ aliquot of DNA was digested overnight at $37^{\circ} \mathrm{C}$ with restriction enzyme XhoI. The digested DNA was fractionated in a $0.7 \%$ agarose gel, transferred to a Hybond ${ }^{T M}-\mathrm{N}^{+}$nylon membrane (Amersham). The plasmid $\mathrm{pExT}_{7}$ was digested by XhoI and $2.0 \mathrm{~kb}$ fragment containing the spider insecticidal gene was used as probe labeled with $\alpha-{ }^{32} \mathrm{P}-\mathrm{dCTP}$ (using Random Primer Label System). Hybridization and detection were performed according to Sambrook et al [15]. 


\section{Inheritance of the marker gene}

The selfed seeds ( $\mathrm{T}_{1}$ generation) of the transformants were sown in solidified MSoK medium with $75 \mathrm{mg} / \mathrm{L}$ kanamycin and cultured at $25 \pm 1^{\circ} \mathrm{C}$. Kanamycin-resistance was scored 7-10 d after sowing. The segregation of the nptII gene in $\mathrm{T}_{1}$ transgenic plants were determined.

\section{Insect bioassays of transgenic plants}

Insecticidal activity of the transgenic plants towards two major rice insects SSB (striped stem borer) and LF (leaffolder) was assayed similar to the described methods [8],[9]. The T0 and $\mathrm{T} 1$ generation of the transgenic rice plants that had been selected for Kanamycin-resistance and showed positive in South-
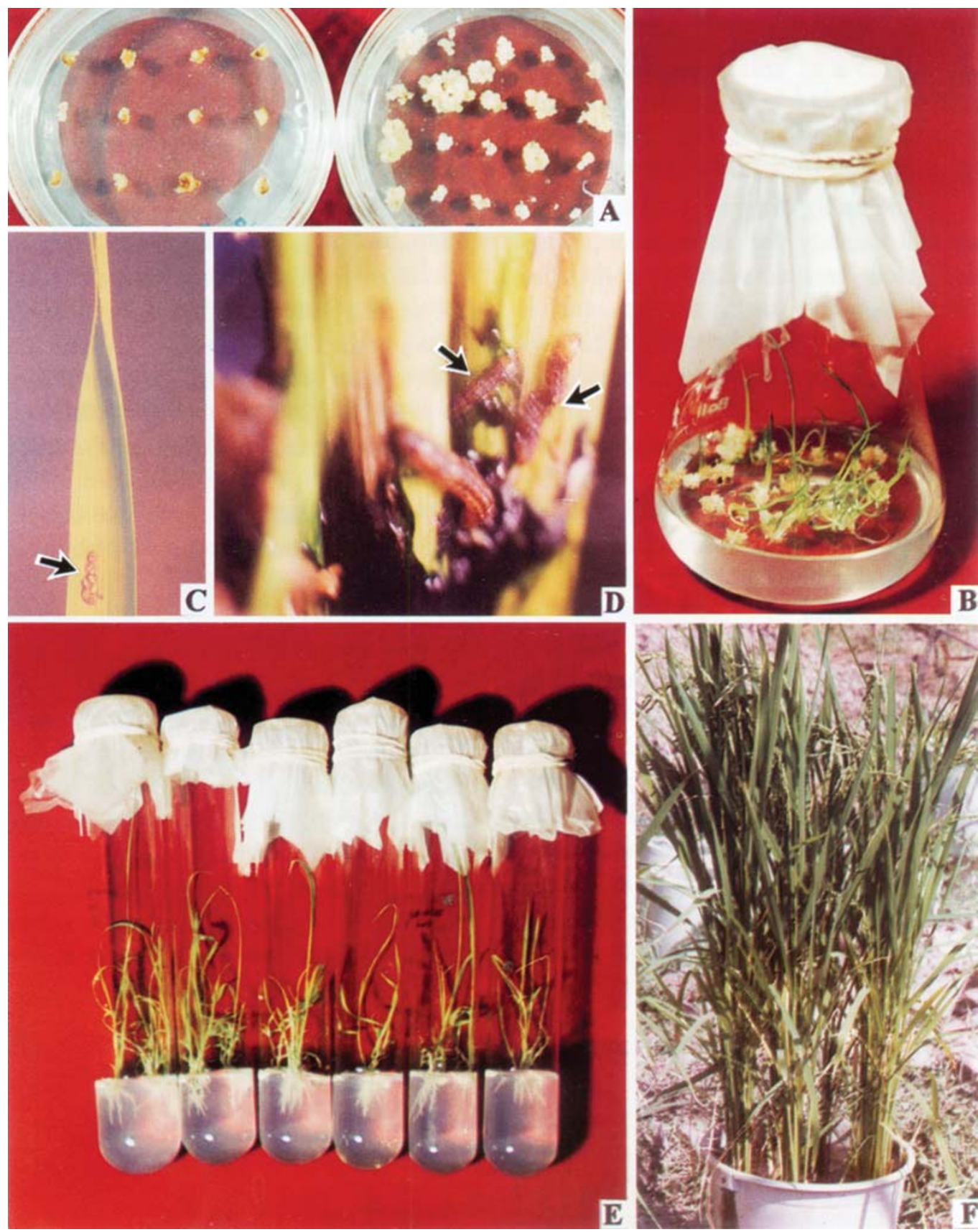

Fig 1. Efficient transformation of rice ( Oryza sativa L.) mediated by Agrobacterium tumefaciens EHA101/pExT (A) Geneticin (G418)-resistant calli (right) after $2 \mathrm{w}$ of selection, left: untransformed control calli; (B) Regenerated resistant shoots on RE-2G medium; (C) Dead leaffolder larvae 5d after leaf feeding on transgenic rice (arrow indicated); (D) Dead striped stem borer larvae $7 \mathrm{~d}$ after leaf feeding on transgenic rice (arrow indicated); (F) Transgenic rice plants after $30 \mathrm{~d}$ of leaf feeding with striped stem borer grew well and produce normal seeds. 
Spider insecticidal gene in rice

ern blot analysis were used to perform insect-bioassays. Each of the tested plants were infected with $15 \sim 30$ second-instar larvae of SSB or LF for $7 \mathrm{~d}$, and larval damage and leaf area consumption or the mortality of insects were monitored. For SSB-resistance test, only larvae found inside the stems were recorded. The larvae of SSB were obtained from the Institute of Entomology, CAS and the larvae of LF were collected from the rice field of Xinzhuang region, Shanghai. Nontransgenic plants, which had no kanamycin-resistance and shown negative in Southern blot analysis, were used as negative controls.

\section{RESULTS AND DISCUSSION}

Co-cultivation, selection and plant regeneration

Various factors including different explant types, A. tumefaciens cell density for inoculation, time period of inoculation and co-culture, co-culture medium, and induction agents in the inoculation and co-culture media were found to affect the efficiency of Agrobacterium-mediated transformation. Optimization of the condition of co-cultivation was a critical importance[3]. Embryogenic callus derived from immature embryos $4 \mathrm{~d}$ after culturing on $\mathrm{N}_{6} \mathrm{D}_{2}$ medium were inoculated and co-cultured with $\mathrm{A}$.

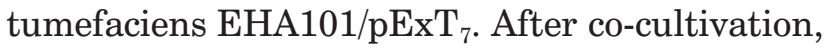
the infected calli were transferred to $\mathrm{N}_{6} \mathrm{D}_{2} \mathrm{C}$ medium $\left(\mathrm{N}_{6} \mathrm{D}_{2}\right.$ medium plus $300 \mathrm{mg} / \mathrm{L}$ cefotaxime) for one week, and then transferred to N6D2-CG medium (Tab 1). After selection for 3-4 w, resistant calli (Fig 1-A) were transferred to RE1-CG medium for shoot development (Fig 1-B). The regenerated shoots were further transferred to RE2-G for full plantlet formation and then rooted on $1 / 2 \mathrm{MSNK}$ medium (Fig 1-E). Efficiency of Agrobacteriummediated transformation of two rice cultivars was listed in Tab 2. The results indicated that, the transformation efficiency of Xiushui 11 reached 71.6\% (resistant callus production) and $60.3 \%$ (transgenic plant regeneration), which was much higher than that of Chunjiang 11 (56.3\% and $36.2 \%$, respectively). It showed that proper genotypes selection is a critical factor in achieving efficiently transformation of rice. This conclusion is in agreement with that of Aldemita[4] and Zhang [5]. The selectable marker present in the T-DNA of the binary vector is also an important factor. The nptII gene present in EHA101 required a long exposure to high concentration of G418 in order to obtain a high efficiency of stably transformed calli. Our results showed that G418 is a good selectable marker, and it allowed good discrimination between transformed and nontransformed tissue. High frequencies of resistant callus production and plantlet regeneration were obtained on G418-containig medium (Tab 2). This conclusion is in contrast to that of Raineri[16], Chan[17] and He[18]. In our study, the high efficiency of obtaining transgenic plants was obtained in immature embryos infected with EHA101/pExT $\mathrm{T}_{7}$ preinduced with AS followed by cocultivation in the presence of AS. In contrast, no transgenic plants obtained without AS treatment (data not shown). It showed that acetosyringone can indeed induce vir gene expression and extend the host range of some A. tumefaciens strains.

\section{Characterization of the transgenic plants}

Transgenic plants were grown in a growth chamber and evaluated for morphology and fertility. More than 110 events were established in soil and examined (data not shown). The majority (about 95\%) of the transformed plants were fertile and produced as many seeds as the seed-derived control plants. We analyzed all of the independently derived transgenic plants by PCR for the presence of the nptII transgenes. As shown in Fig 2, we found that the 7 transformed plants randomly

Tab 2. Efficiency of Agrobacterium-mediated transformation in two rice cultivars

\begin{tabular}{|c|c|c|c|c|c|c|c|}
\hline \multirow[t]{2}{*}{ Rice cultivar } & \multirow{2}{*}{$\begin{array}{l}\text { Experi- } \\
\text { Ment } \\
\text { No. }\end{array}$} & \multirow{2}{*}{$\begin{array}{l}\text { Number of co- } \\
\text { cultivated calli } \\
\text { (A) }\end{array}$} & \multirow{2}{*}{$\begin{array}{l}\text { No. of G418 } \\
\text { calli } \\
\text { (B) }\end{array}$} & \multirow{2}{*}{$\begin{array}{l}\text { No. of callus } \\
\text { producing } \\
\text { plants (C) }\end{array}$} & \multirow{2}{*}{$\begin{array}{l}\text { No. of } \\
\text { G-418 } \\
\text { plants }\end{array}$} & \multicolumn{2}{|c|}{$\begin{array}{l}\text { Transformation } \\
\text { efficiency (\%) }\end{array}$} \\
\hline & & & & & & $\mathrm{B} / \mathrm{A}$ & $\mathrm{C} / \mathrm{A}$ \\
\hline \multirow[t]{4}{*}{ Xiushui 11} & 1 & 108 & 74 & 65 & 229 & 68.5 & 60.2 \\
\hline & 2 & 135 & 98 & 83 & 274 & 72.6 & 61.5 \\
\hline & 3 & 92 & 68 & 54 & 117 & 73.9 & 58.7 \\
\hline & Total & 335 & 240 & 202 & 620 & $71.6^{a}$ & $60.3^{a}$ \\
\hline \multirow[t]{4}{*}{ Chunjiang 11} & 1 & 68 & 35 & 29 & 86 & 51.5 & 42.6 \\
\hline & 2 & 93 & 46 & 30 & 112 & 49.5 & 32.3 \\
\hline & 3 & 118 & 76 & 42 & 153 & 64.4 & 35.6 \\
\hline & Total & 279 & 157 & 101 & 351 & $56.3^{b}$ & $36.2^{b}$ \\
\hline
\end{tabular}

${ }^{\mathrm{a}, \mathrm{b}}$ Average number of transformation efficiency. 
tested contained the $521 \mathrm{bp}$ fragment of $n p t I I$ gene, and the size of the amplified fragment is in coincidence with that of the positive control. It indicated that the foreign nptII gene had been integrated into the rice genome.

The status of the transgenic plants were characterized by Southern blot analysis in detail, and the copy number of the SpI gene in transgenic plants were estimated. DNA was extracted from leaf tissue of $45 \mathrm{~T}_{0}$ plants derived from independent events, and digested with XhoI and hybridized with a probe $(2.0 \mathrm{~kb}$ XhoI-digested fragment of $\mathrm{pExT}_{7}$ containing the spider insecticidal gene) labeled with $\alpha-{ }^{32} \mathrm{P}$-dCTP. We analyzed 9 independently derived $\mathrm{T}_{0}$ transgenic plants by Southern blot (Fig 3). Unique and complex hybridization patterns were revealed, indicating that these plants were indeed originated from independent events. Because XhoI cuts only once in SpI probe, the number of hybridization bands is in agreement with the copy number of T-DNA integrated into transgenic plants. Among the 9 transgenic plants tested, all of them showed positive hybridization

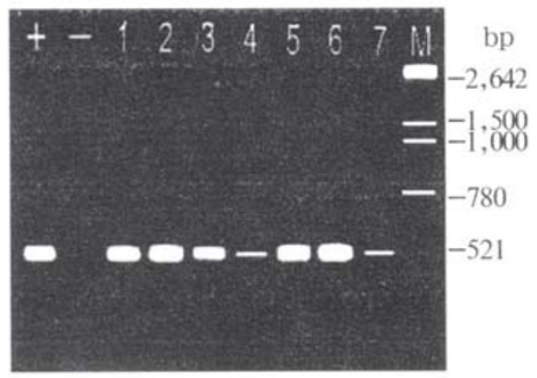

Fig 2. PCR assay of nptII gene in transgenic rice plants $M$ : Molecular weight marker; +: Positive control (521bp fragment from pGIH; -: An untransformed control plant; 1-7: Transgenic plants.

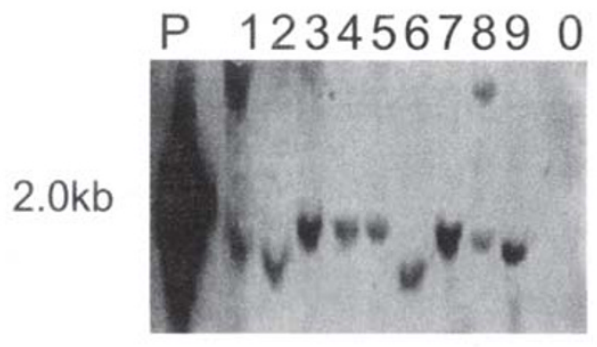

Fig 3. Southern blot analysis of transgenic rice plants $P$ : Positive control (2.0kb XhoI fragment from $\mathrm{pExT}_{7}$ ); O: An untransformed control plant; 1-9: Transgenic plants. bands of SpI gene. Most of the hybridization bands were between 1.8 and $4.0 \mathrm{~kb}$. Most of the transgenic plants carried one copy of the SpI gene, with only two plants (Fig 3, plant No.1 and No.8) carring two copies of the SpI gene. No positive hybridization bands could be found in untransformed plants as a control. Thus, Southern blot analysis confirmed that the SpI gene had stably integrated into the genome of transgenic plants.

Inheritance of transgenes through sexual generation

After transplanting to soil, all transgenic rice plants grew well and produced normal seeds (Fig 1-F). Inheritance of the marker gene nptII was investigated. All the selfed seeds of $\mathrm{T}_{1}$ generation, when sowed in solidified MS0K medium with 75 $\mathrm{mg} / \mathrm{L}$ kanamycin, can produce some green shoots normally, whereas, all the control seeds from untransformed plants died. Segregation for kanamycin resistance were observed in 12 independently transformed plant lines (Tab 3). The results indicated that the segregating ratios in most of the lines tested fit the 3:1 model for single dominant gene inheritance. Exception was found in line X5, in which there were more sensitive plants than expected from the Mendelian model. The results of genetic analysis of the $\mathrm{T}_{1}$ generation further demonstrated the stable incorporation of T-DNA into the rice genome and inheritance in the subsequent generations.

\section{Insecticidal activity of $T_{1}$ transgenic plants}

Our long-term goals are to improve the quality of rice by using an approach in which multiple disease- and insect-resistant traits can be introduced into the same lines [2]. In our experiment, the insecticidal activity of transgenic rice plants on LF and SSB wereinvestigated (Tab 4 and Tab 5). For LF insect-resistance test, the leaves of 117 transgenic plants from two transgenic lines of Xiushui 11 and Chunjiang 11 were infested with the larvae of the second instar stage of LF. Seven d after infestation, the insecticidal activity and the resistance level were examined ( $\mathrm{Tab} 4$ ). Average mortality of $38.4 \%-61.2 \%$ was observed in the two transgenic lines for the two rice varieties $7 \mathrm{~d}$ after treatment, whereas in the control plants, mortality was $<1 \%$ in most cases. Significant leaf damages 
were observed in control plants as a result of LF feeding, whereas in transgenic plants, there was little detectable damage (Fig 1-C). For SSB insectresistance test, stem cuttings and, in most cases, whole plants from eight transgenic lines $\left(\mathrm{N}_{1}\right.$ to $\left.\mathrm{N}_{8}\right)$ carrying SpI were infested with the larvae of the second instar stage of SSB. The corrected mortality after $7 \mathrm{~d}$ of insect feeding was examined (Tab $5)$. Only larvae found inside the stems were recorded. Two to seven $d$ after infestation, escape of insects from the stem was found in some transgenic plants infested and part of them died later (Fig 1-D). Corrected mortality of 36\%-75\% was observed in most of the transgenic lines $\left(\mathrm{N}_{1}, \mathrm{~N}_{3^{-}}\right.$ $\mathrm{N}_{8}$ ), which were found to be highly toxic to SSB.
These plants produce seeds normally after $30 \mathrm{~d}$ of treatment (Fig 1-F). One exception was found in transgenic plant line $\mathrm{N}_{2}$. In contrast, all seedderived plants as control growth abnormally after $30 \mathrm{~d}$ of treatment.

In conclusion, we have obtained over 970 transgenic rice plants by Agrobacterium-mediated transformation procedure. The transgenes in most of the plants analysed were inherited as Mendelian traits. Feeding assays with T1 plants from 10 independent transgenic lines confirmed that the transgenic plants were highly toxic to LF and SSB larvae.

\section{ACKNOWLEDGMENTS}

Tab 3. Genetic analysis of $\mathrm{T} 1$ generation of transgenic rice plants

\begin{tabular}{|c|c|c|c|c|c|c|}
\hline \multicolumn{5}{|c|}{ Number of T1 seedlingsRatio of segregation } & \multicolumn{2}{|l|}{$r$ value for } \\
\hline Rice cultivar & Transfomants & Kanr & Kans & (Kanr/Kans) & $\mathrm{c} 2$ & $3: 1$ ratio \\
\hline \multirow[t]{6}{*}{ Xiushui 11} & $\mathrm{X} 1$ & 21 & 9 & 2.3 & 0.400 & 0.55 \\
\hline & $\mathrm{X} 2$ & 23 & 7 & 3. & 0.044 & 0.82 \\
\hline & $\mathrm{X} 3$ & 25 & 5 & 5.0 & 1.112 & 0.19 \\
\hline & $\mathrm{X} 4$ & 17 & 4 & 4.3 & 0.397 & 0.54 \\
\hline & $\mathrm{X} 5$ & 11 & 14 & 0.8 & 12.813 & $<0.01$ \\
\hline & $\mathrm{X} 6$ & 18 & 7 & 2.6 & 0.120 & 0.74 \\
\hline \multirow[t]{6}{*}{ Chunjiang 11} & $\mathrm{C} 1$ & 21 & 8 & 2.6 & 0.103 & 0.75 \\
\hline & $\mathrm{C} 2$ & 12 & 3 & 4.0 & 0.143 & 0.72 \\
\hline & C3 & 9 & 0 & - & 3.000 & 0.09 \\
\hline & $\mathrm{C} 4$ & 17 & 6 & 2.8 & 0.014 & 0.95 \\
\hline & C5 & 18 & 5 & 3.6 & 0.130 & 0.73 \\
\hline & C6 & 15 & 6 & 2.5 & 0.143 & 0.72 \\
\hline
\end{tabular}

Tab 4. Insecticidal activity of $\mathrm{T} 1$ transgenic rice on leaffolder larvae

\begin{tabular}{lccc}
\hline & & Average mortality & \\
Rice materials & Number of plants tested & $7 \mathrm{~d}$ after treatment (\%) & Resistance level \\
\hline Control & 40 & 0 & Highly sensitive \\
Xiushui-SpI & 78 & $61.2 \pm 10.7$ & Highly resistant \\
Chunjiang-SpI & 39 & $38.4 \pm 7.6$ & Moderately resistant \\
\hline
\end{tabular}

Tab 5. Insecticidal activity of $\mathrm{T} 1$, transgenic rice (Xiushui 11) on striped stem borer larvae

\begin{tabular}{ccccc}
\hline & Average weight of & Mortality within & \multicolumn{2}{c}{ Formation of flowers } \\
\hline Transgenic & survived larvae in $7 \mathrm{~d}$ & $7 \mathrm{~d}$ after treatment & Corrected mortality & and seeds after 30 d of \\
of treatment $(\mathrm{mg})$ & $(\%)$ & $(\%)$ & 0 & Abnormal \\
lines & $81.2 \pm 10.9$ & $2.7 \pm 0.3$ & 64.4 & Normal \\
$\mathrm{N}_{1}$ & $34.7 \pm 4.8$ & $65.4 \pm 10.6$ & 16.1 & Abnormal \\
$\mathrm{N}_{2}$ & $64.5 \pm 7.0$ & $18.4 \pm 2.8$ & 47.3 & Normal \\
$\mathrm{N}_{3}$ & $72.9 \pm 9.4$ & $48.7 \pm 11.2$ & 66.7 & Normal \\
$\mathrm{N}_{4}$ & $51.8 \pm 12.9$ & $67.6 \pm 10.4$ & 74.5 & Normal \\
$\mathrm{N}_{5}$ & $23.7 \pm 8.9$ & $75.2 \pm 14.1$ & 44.3 & Normal \\
$\mathrm{N}_{6}$ & $48.3 \pm 7.2$ & $45.8 \pm 4.9$ & 35.9 & Normal \\
$\mathrm{N}_{7}$ & $52.4 \pm 8.7$ & $37.6 \pm 10.8$ & 69.7 & Normal \\
$\mathrm{N}_{8}$ & $38.6 \pm 11.5$ & $70.5 \pm 18$. & \\
\hline
\end{tabular}


The authors are very grateful to Prof. TANG Zhen Hua and ZHUANG Pei Jun, Dr. WU Jun of Institute of Entomology, CAS for their useful suggestion and kind help in insect resistance tests. We also thank Prof. FANG Ping Yi for providing rice materials used in this experiment. Life Science Special Fund of CAS (No. Stz-3-03) Supported by the Ministry of Finance.

\section{REFERENCES}

[1] Christou P. Rice transformation: bombardment. Plant Mol Biol 1997; 35:197-203.

[2] Tang KX, Porntip T, Xu YN, Sun XF, Gatehouse JA, Ronald PC, Qi HX, Lu XG, Christou P, Kohli A. Particle-bombardment-mediated co-transformation of elite Chinese rice cultivars with genes conferring resistance to bacterial blight and sap-sucking insect pests. Planta 1999; 208:552-63.

[3] Hiei Y, Ohta S, Komari T, Kumashiro T. Efficient transformation of rice (Oryza sativa L.) mediated by Agrobacterium and sequence analysis of the boundaries of the T-DNA. Plant J 1994; 6:271-82.

[4] Aldemita RR, Hodges TK. Agrobacterium tumefaciencesmediated transformation of japonica and indica rice varieties. Planta 1996; 199:612-7.

[5] Liu QQ, Zhang JL, Wang ZY, Hong MM., Gu MH. A highly efficient transformation system mediated by Agrobacterium tumefaciences in rice. Acta Phytophysiol Sin 1998; 24:259-71.

[6] Zhang B, Huang JQ, Wei ZM. A quick method to estimate the T-DNA copy number in transgenic rice using inverse PCR (IPCR). Acta Biol Exp Sin 1999; 32:207-11.

[7] Huang JQ, Wei ZM, An HL, Xu SP, Zhang B. High efficiency of genetic transformation of rice using Agrobacterium mediated procedure. Acta Botanica Sin 2000; 42 :1172-8.

[8] Huang JQ, Wei ZM, An HL, Xu SP. Agrobacterium tumefaciences-mediated transformation of rice with insecticidal Bacillus thuringiensis gene and bioassay of the transgenic plants. Acta Phytophysiol Sin 2000; 26: $519-24$

[9] Cheng X, Sardana R, Kaplan H, Altosaar I. Agrobacteriumtransformed of rice plants expression cryIA(b) and cryIA (c) genes are highly toxic to striped stem borer and yellow stem borer. Proc Natl Acad USA 1988; 95:276772.

[10] Xiang YB, Liang ZQ, Gao MW, Shu QY, Ye GY, Cheng XY, Altosaar I. Agrobacterium- mediated transformation of insecticidal Bacillus thuringiensis cryIA(b) and cryIA (c) genes and their expression in rice. Chin $\mathrm{J}$ Biotech 1999; 15:494-500.

[11] Zhu ZQ, Wang JJ, Sun JS, Xu Z, Yin GC, Zhu ZY, Bi FY. Establishment of an efficient medium for anther culture of rice through comparative experiments on the nitrogen sources. Sci Sin 1975; 18:659-68.

[12] Toriyama K, Hinata K. Cell suspension and protoplast culture in rice. Plant Sci 1985; 41: 179-83.

[13] Murashige T, Skoog F. A revised medium for rapid growth and bioassays with tobacco tissue culture. Physiol Plant 1962; 15:473-79.

[14] Murray MG, Thompson WF. Rapid isolation of high molecular weight plant DNA. Nucl Acid Res 1980; 8: 4321-5.

[15] Sambrook J, Fritsh EF, Maniatis T. Molecular Cloning: A Laboratory Manual. Cold Spring Harbor, NY: Cold Spring Harbor Laboratory Press. 1989.

[16] Raineri DM, Bottino P, Gordon MP, Nester EW. Agrobacterium tumefaciens-mediated transformation of rice (Oryza sativa L.). Bio/Technology 1990; 8:33-8.

[17] Chan MT, Chang HH, Ho SL, Tong WF, Yu SM. Agrobacterium tumefaciens-mediated production of transgenic rice plants expressing a chimeric alpha amylase promotorb-glucuronidase gene. Plant Mol Biol 1993; 22:491-6.

[18] He YK, Xue WX, Sun YD, Yu XH, Liu PL. Leaf head formation of the progenies of transgenic plants of Chinese cabbage with exogenous auxin genes. Cell Research 2000; 10:151-60. 